\title{
The Effect of the Application of Edible Coatings on or before Ultraviolet Treatment on Postharvested Longan Fruits
}

\author{
Mee Gie Lin, ${ }^{1}$ Ola Lasekan, ${ }^{1}$ Nazamid Saari, ${ }^{2}$ and Siti Khairunniza-Bejo ${ }^{3}$ \\ ${ }^{1}$ Department of Food Technology, Faculty of Food Science and Technology, Universiti Putra Malaysia, 43400, Serdang, Malaysia \\ ${ }^{2}$ Department of Food Science, Faculty of Food Science and Technology, Universiti Putra Malaysia, 43400, Serdang, Malaysia \\ ${ }^{3}$ Department of Biological and Agricultural Engineering, Faculty of Engineering, Universiti Putra Malaysia, 43400, Serdang, Malaysia
}

Correspondence should be addressed to Ola Lasekan; olaniny56@gmail.com

Received 7 June 2017; Revised 18 August 2017; Accepted 5 September 2017; Published 8 October 2017

Academic Editor: Alejandro Hernández

Copyright (C) 2017 Mee Gie Lin et al. This is an open access article distributed under the Creative Commons Attribution License, which permits unrestricted use, distribution, and reproduction in any medium, provided the original work is properly cited.

\begin{abstract}
This study compared the effect of application of edible coating on or before ultraviolet treatment on postharvest longan fruits. The treated longan fruits were examined for weight loss, respiration rate, surface color changes, enzymatic activities (PPO, POD, and PAL), and total phenolic contents throughout the 7 storage days at ambient temperature. In addition, coat homogeneity was examined and cell structure of longan flesh at the end of storage was observed. The results showed that when UV was applied before coating (i.e., chitosan or carrageenan), it had relatively lower PPO and PAL activities and retained higher TPC in longan pericarp. However, the changes in enzymatic activities did not affect the surface lightness and browning index as they were more influenced by the type of coating, in which combination treatments with carrageenan showed higher surface lightness and lower browning index compared to treatment combinations containing chitosan. However, when UV treatment preceded coating, the combinations of UV plus chitosan coating produced lower PPO and PAL activities and retained better cell structure with less damage than the combinations of UV plus carrageenan coating. UV plus carrageenan coating showed relatively higher weight loss and respiration rate, with cell structure exhibiting bigger intercellular spaces at the end of storage. Therefore, application of UV treatment followed by chitosan coating was found to be the best treatment combination for controlling enzymatic activities and reducing senescence rate of longan fruits.
\end{abstract}

\section{Introduction}

Longan fruit (Dimocarpus longan) is a nonclimacteric tropical and subtropical fruit. It has high commercial value due to its flavor and high content of vitamin $\mathrm{C}$, minerals, and bioactive polyphenols $[1,2]$. However, harvested longan fruit has a very short shelf life of three days under ambient temperature [3-5]. Pericarp browning is one of the major problems in longan fruit. The most popular commercial method for preventing fruit browning and fruit decay is by sulphur dioxide fumigation [6]. However, sulphur dioxide fumigation leaves sulphite residues and toxic ingredients that are harmful to health $[6,7]$. In recent years, the increased demand for fresh commodities which are free of pesticides has diverted attention towards nonchemical methods of preserving and improving qualities of fresh commodities. Some of the innovative nonchemical methods of preservation are ultraviolet treatment and edible coating.
Prestorage exposure of fresh fruits to shortwave ultraviolet radiation (UV-C) has been successful in reducing decay, controlling natural infections, reducing respiration rate, controlling rot development, and maintaining overall quality in postharvest fruits and vegetables $[8,9]$. UV-C was also proven to delay ripening in postharvest fruits and vegetables [10]. In another study, UV was able to decrease enzyme activities in cell wall and thus delayed fruits softening [11]. UV-C was also reported to induce antioxidant activity [12]. Other than solid food, beneficial effect of UV-C on liquid foods has been reported. For example, liquid foods such as milk, liquid egg white, and apple cider have successfully been treated with UV-C irradiation [13-15].

The use of edible coating is another safe method of prolonging storability of perishable crops [16]. Edible coatings are mostly derived from biological sources. Application of edible coating on fresh fruits is able to reduce quality changes and slow down quantity losses, for example, moisture loss 
by controlling and modifying the internal atmosphere of the individual fruits [17]. The edible coating material forms thin layer on the surface of food and gives a selective barrier against moisture, oxygen, and carbon dioxide [16]. If a film or coating with the appropriate permeability is chosen, a controlled respiratory exchange can be established and thus the preservation of fresh produce can be achieved [18].

Furthermore, studies have shown that the combination of UV-C with other preservative methods has achieved great success in quality maintenance in fresh produce. For example, Marquenie et al. [19] examined the effect of ultraviolet (UV) and heat treatment on strawberries and sweet cherry and they obtained lower numbers of defects, reduced storage rot, and retarded fungal growth. Strawberry treated with edible coating $(1.0 \% \mathrm{w} / \mathrm{v}$ carboxymethyl cellulose) followed by $2.0 \mathrm{kGY}$ gamma irradiation and subsequently stored in chilled temperature was found to maintain high quality, delayed decay, and the appearance of mold growth, and it exhibited a longer shelf life up to 18 days [20]. In red table grapes, UV-C irradiation $\left(6 \mathrm{~kJ} / \mathrm{m}^{2}\right)$ followed by $0.5 \%$ chitosan and incubation at $20^{\circ} \mathrm{C}$ for 24 hours before refrigerated storage was found to have increased resveratrol content, maintained high sensory quality, and reduced fungal decay [21]. Moreover, the sequence of applying preservative treatments has not been fully studied. However, there was a study that showed that the sequence had effect on product quality. Marquenie et al. [19] have shown that when UV-C treatment precedes heat treatment, a significantly better strawberry quality was obtained. Thus, the aim of this study was to determine the effect of the application of different edible coatings on or before UV-C treatment in controlling enzymatic activities and reducing senescence rate of longan fruits.

\section{Materials and Methods}

2.1. Plant Material Preparation. Longan fruits (Dimocarpus longan Lour. cv. Diamond) at commercial maturity were harvested from an orchard in Sepang, Selangor state, Malaysia, and transported to the Universiti Putra Malaysia within 2 hours. Longan fruits that are of uniform size, shape, and color and that are free from any blemish or defects were selected, washed, and dipped in sodium hypochlorite $(100 \mathrm{ppm})$ to reduce surface contamination. After that, the fruits were pretreated by dipping in a solution of $1 \%$ ascorbic acid for 5 minutes [22].

Ascorbic acid is a reducing agent which reduces enzymatic browning by maintaining lower polyphenol oxidase (PPO) activity. In detail, ascorbic acid plays its role in reducing o-quinones back to dihydroxy polyphenols; therefore, it plays an important role as an antibrowning agent. However, the effect of ascorbic acid is temporary. It leads to browning pigment formation when it is completely oxidized [23]. Therefore, ascorbic acid treatment alone is not sufficient in controlling browning and it is used as a pretreatment.

2.2. Postharvest Treatment. In this study, the effect of UV-C irradiation and edible coating on longan fruits stored at ambient temperature $\left(28 \pm 1^{\circ} \mathrm{C}\right)$ was evaluated. For the
UV-C irradiation, UV light at $254 \mathrm{~nm}$ with a dosage of $11.4 \mathrm{~kJ} / \mathrm{m}^{2}$ was applied. These formulations were the results of a preliminary study (data not shown). Meanwhile, for the edible coating, two types of coatings were tested, which were chitosan- and carrageenan-based edible coatings. The chitosan-based coating (CHI) formulation was $1.29 \%(\mathrm{w} / \mathrm{v})$ chitosan, $0.42 \%(\mathrm{w} / \mathrm{v})$ glycerol, and $0.025 \%(\mathrm{w} / \mathrm{v})$ sunflower oil, while the carrageenan-based coating (CAR) consisted of $1.49 \%(\mathrm{w} / \mathrm{v})$ kappa carrageenan, $0.03 \%(\mathrm{w} / \mathrm{v})$ glycerol, and $0.025 \%(\mathrm{w} / \mathrm{v})$ sunflower oil. These formulations were the results of a preliminary study (data not shown). Thus, the evaluated treatments were as follows:

(1) Carrageenan-based coating followed by UV irradiation $(\mathrm{CAR}+\mathrm{UV})$

(2) Chitosan-based coating followed by UV irradiation $(\mathrm{CHI}+\mathrm{UV})$

(3) UV irradiation followed by carrageenan-based coating (UV + CAR)

(4) UV irradiation followed by chitosan-based coating $(\mathrm{UV}+\mathrm{CHI})$

(5) Longan fruits not subjected to either coating or UV irradiation (Control).

The treated longan fruits were stored at ambient temperature $\left(28 \pm 1^{\circ} \mathrm{C}\right)$ for 7 days for analysis. The studied duration was based on a preliminary observation on color changes of treated longan fruits compared to untreated longan fruits (data not shown).

2.3. UV-C Irradiation. For the application of UV-C, a device of UV-C irradiation was built up from two unfiltered germicidal emitting lamps (VL-215G, Vilber Lourmat, Marne la Vallee, France) at $254 \mathrm{~nm}$ with a reflector for optimum UV irradiance. The UV lamps were fixed at $15 \mathrm{~cm}$ above the sample placing spot and these were enclosed in a wooden box covered with aluminum foil. Fifteen minutes prior to use, the device was switched on for the purpose of stabilization. The UV-C intensities transmitted from the lamps were measured using a UVX radiometer (Ultra-Violet Products Ltd, Cambridge, UK). The UV-C intensity was determined as a mean of 20 readings within a uniform area of the radiation field.

2.4. Edible Coating. Chitosan solution was prepared according to Jiang et al. [24]. $500 \mathrm{~mL}$ of chitosan solution was prepared by dissolving $1.29 \%(\mathrm{w} / \mathrm{v})$ chitosan powder (low molecular weight of 190000-310000 Da, deacetylation degree of $75-85 \%$ ) (Sigma-Aldrich, USA) in $200 \mathrm{~mL}$ of distilled water in which $0.5 \%(\mathrm{v} / \mathrm{v})$ glacial acetic acid (Reagent grade, Merck, USA) was added to dissolve the chitosan. The $\mathrm{pH}$ value was adjusted to 5.6 using $0.1 \mathrm{M}$ sodium hydroxide (AR grade, Friendemann Schmidt, Germany). Glycerol (Sigma-Aldrich, USA) of $0.42 \%(\mathrm{w} / \mathrm{v})$ was added as a plasticizer while sunflower oil (Melrose; purchased at LOHAS) of $0.025 \%(\mathrm{w} / \mathrm{v})$ was used as a surfactant. The solution was made up to $500 \mathrm{~mL}$ and after that homogenized and degassed ultrasonically. Meanwhile, carrageenan solution was prepared according to Ribeiro et al. [25]. Carrageenan solution was made by 
dispersing $1.49 \%(\mathrm{w} / \mathrm{v})$ kappa carrageenan powder (SigmaAldrich, USA) in distilled water and heated at $80^{\circ} \mathrm{C}$ for $10 \mathrm{~min}$; the $\mathrm{pH}$ was adjusted to $5.6 \mathrm{using} 5 \%(\mathrm{w} / \mathrm{v})$ citric acid solution (CP grade, R\&M Chemicals, UK). Glycerol at $0.03 \%(w / v)$ and sunflower oil at $0.025 \%(\mathrm{w} / \mathrm{v})$ were added and underwent homogenization and degassed ultrasonically. Longan fruits were submerged in these solutions, respectively, for 2 minutes and allowed to drain for 3 hours at ambient temperature.

\subsection{Analysis}

2.5.1. Analysis of Weight Loss. For each treatment, the measurement of weight loss was carried out on ten fruits in each replication. The weight loss was determined gravimetrically using analytical balance (Sartorius TE214S, Switzerland). The weight differences after storage compared to initial weight were expressed in percentage [26].

2.6. Respiration Rate. The respiratory rate was determined using a 6600 headspace oxygen/carbon dioxide analyzer (Illinois Instruments Inc., Illinois, US). Ten coated longan fruits (approximately $100 \mathrm{~g}$ ) were placed in glass jar and incubated at room temperature $\left(28^{\circ} \mathrm{C}\right)$ for $1 \mathrm{~h}$. The glass jar had air-tight screw caps and rubber septum to allow headspace sampling. Percentages of carbon dioxide were recorded when the readings were stabilized. The results were calculated and expressed as $\mathrm{ml} \mathrm{CO}_{2} / \mathrm{kg} \cdot \mathrm{h}[26]$.

2.7. Surface Lightness and Browning Index. Surface lightness was determined using HunterLab UltraScan PRO spectrophotometer attached to EasyMatch QC software (Hunter Associate Laboratory Inc., US). The spectrophotometer used CIE LAB color space $\left(L^{*}, a^{*}\right.$, and $\left.b^{*}\right)$ and pulsed xenon lamps as light sources, and observer degree of 10 and reflectance specular component were included. The spectrophotometer was calibrated with black calibration light trap and calibrated instrument white tile. For each treatment, peel color of ten individual fruits per replicates was measured. Readings were taken from stem end, mid region, and blossom end of each fruit. Reading of $L$ value was taken to represent the lightness of the fruit $(0=$ black; $100=$ white $)$ [27]. The browning index (BI) was then determined using the following equations:

$$
\mathrm{BI}=\left[\frac{100(X-0.31)}{0.17}\right],
$$

where $X=\left(a^{*}+1.75 L^{*}\right) /\left(5.645 L^{*}+a^{*}-0.3012 b^{*}\right)$

2.8. Extraction of $P P O$ and POD. Pericarp tissues $(5 \mathrm{~g})$ from 20 fruits were homogenized in $20 \mathrm{~mL}$ of $0.05 \mathrm{M}$ phosphate buffer, $\mathrm{pH} 7.0$ together with $0.5 \mathrm{~g}$ polyvinylpyrrolidone, and followed by centrifugation for $20 \mathrm{~min}$ at $12000 \mathrm{~g}$ and $4^{\circ} \mathrm{C}$ (Sigma 3-18K, Sartorius, Germany). The supernatant was collected as the crude enzyme extract and used for the determination of PPO and POD activities [28]. The extractions were repeated for longan pulp.

2.9. $P P O$ Activity. Reaction mixture assay containing $1 \mathrm{~mL}$ of supernatant was mixed with $0.5 \mathrm{~mL}$ of phosphate buffer and
$0.5 \mathrm{~mL}$ of $0.1 \mathrm{M} 4$-methylcatechol. PPO activity was recorded by the increase in absorbance at $410 \mathrm{~nm}$ for $3 \mathrm{~min}$ at $25^{\circ} \mathrm{C}$, using a spectrophotometer (GENESYS 10S UV-Vis, Thermo Scientific, USA). One unit of enzyme activity was defined as the amount that caused a change of 0.001 in the absorbance per minute $[28,29]$.

2.10. POD Activity. Reaction mixture assay containing $25 \mu \mathrm{L}$ of supernatant was mixed with $2.775 \mathrm{~mL}$ of $0.05 \mathrm{M}$ phosphate buffer, $0.1 \mathrm{~mL}$ of $1 \% \mathrm{H}_{2} \mathrm{O}_{2}$, and $0.1 \mathrm{~mL}$ of $4 \%$ guaiacol in a total volume of $3 \mathrm{~mL}$. The increase in the absorbance at $470 \mathrm{~nm}$ was recorded for $2 \mathrm{~min}$. One unit of enzyme activity was defined as the amount that caused a change of 0.01 in the absorbance per minute $[28,30]$.

2.11. Extraction of PAL. Pericarp tissues ( $5 \mathrm{~g}$ ) from 20 longan fruits were homogenized in $20 \mathrm{~mL}$ of $0.1 \mathrm{M} \mathrm{Na}$ borate buffer, $\mathrm{pH} 8.0$ containing $0.5 \mathrm{~g}$ polyvinylpyrrolidone, $5 \mathrm{mM} \beta$ mercaptoethanol, and $2 \mathrm{mM}$ EDTA at $4^{\circ} \mathrm{C}$. The homogenate was centrifuged for $20 \mathrm{~min}$ at $12000 \mathrm{~g}$ and $4^{\circ} \mathrm{C}$ and supernatant was collected for enzyme assay [28, 31]. The extractions were repeated for longan pulp.

2.12. PAL Activity. The reaction mixture consisted of $0.1 \mathrm{~mL}$ enzyme extract and $2.9 \mathrm{~mL}$ of $0.1 \mathrm{M} \mathrm{Na}$ borate buffer containing $3 \mathrm{mM} \mathrm{L}$-phenylalanine. The mixture was incubated for $1 \mathrm{~h}$ at $37^{\circ} \mathrm{C}$. The increase in absorbance at $290 \mathrm{~nm}$, due to the formation of trans-cinnamate, was measured spectrophotometrically. One unit of enzyme activity was defined as the amount that caused an increase of 0.01 in the absorbance per hour.

2.13. Total Phenolic Content (TPC) Assay. Total phenolic content (TPC) was determined according to the method of Singleton and Rossi [32]. Longan exocarp (2g) from 20 fruits was homogenized in $20 \mathrm{~mL}$ of $80 \%$ ethanol for $1 \mathrm{~min}$ and then centrifuged for $20 \mathrm{~min}$ at $12000 \mathrm{~g}$ and $4^{\circ} \mathrm{C} .200 \mu \mathrm{L}$ of the clear supernatant was mixed with $10 \mathrm{~mL}$ of $10 \%$ Folin-Ciocalteu reagent $(\mathrm{v} / \mathrm{v})$ for $8 \mathrm{~min}$. It was then added to $8.0 \mathrm{~mL}$ of $7.5 \%$ sodium carbonate $(\mathrm{w} / \mathrm{v})$. The mixture was incubated for $2 \mathrm{~h}$ at $30^{\circ} \mathrm{C}$ and the absorbance was read at $765 \mathrm{~nm}$. A standard curve of Gallic acid was used to quantify the total phenolic content. The TPC assays were repeated for longan pulp.

2.14. Coat Homogeneity. The coating of fruits was achieved by immersion followed by drying as discussed above. The homogeneity of the coatings was examined by obtaining cross section of the coated fruits. Samples were stained using a solution of toluidine blue and observed under Meiji EMZ5TRD stereo microscope (Meiji Techno Co., Ltd., Tokyo, Japan). Thickness was then measured randomly from different sections using Nikon Eclipse 80i light microscope (Nikon Instech Co., Ltd., Tokyo, Japan).

2.15. Microscopic Analysis. The structural changes of longan flesh tissues on day 2 and day 7 were observed through light microscope as described by Ferrari et al. [33]. Random tissue samples $(5 \times 3 \times 3 \mathrm{~mm})$ from surface of longan flesh were fixed in $40 \mathrm{~g} / \mathrm{kg}$ glutaraldehyde in phosphate buffer $(\mathrm{pH}$ 
TABLE 1: The effect of different UV-C and edible coating combinations on weight loss in longan fruits.

\begin{tabular}{lcccc}
\hline Treatment & & \multicolumn{3}{c}{ Weight loss (\%) } \\
& Day 0 & Day 3 & Day 5 & Day 7 \\
\hline CAR + UV & n.d. & $2.42 \pm 0.09^{\mathrm{a}, \mathrm{C}}$ & $4.71 \pm 0.35^{\mathrm{a}, \mathrm{B}}$ & $8.23 \pm 0.39^{\mathrm{a}, \mathrm{A}}$ \\
$\mathrm{CHI}+\mathrm{UV}$ & n.d. & $2.01 \pm 0.30^{\mathrm{a}, \mathrm{C}}$ & $4.05 \pm 0.26^{\mathrm{a}, \mathrm{B}}$ & $7.28 \pm 0.49^{\mathrm{a}, \mathrm{A}}$ \\
$\mathrm{UV}+\mathrm{CAR}$ & n.d. & $2.33 \pm 0.42^{\mathrm{a}, \mathrm{C}}$ & $4.62 \pm 0.74^{\mathrm{a}, \mathrm{B}}$ & $8.68 \pm 0.77^{\mathrm{a}, \mathrm{A}}$ \\
$\mathrm{UV}+\mathrm{CHI}$ & n.d. & $1.89 \pm 0.35^{\mathrm{a}, \mathrm{C}}$ & $4.03 \pm 0.70^{\mathrm{a}, \mathrm{B}}$ & $7.34 \pm 0.46^{\mathrm{a}, \mathrm{A}}$ \\
\hline
\end{tabular}

Different lowercase letter indicates significant difference at $p<0.05$ in each storage day; different uppercase letter indicates significant difference at $p<0.05$ in each treatment; n.d.: not detected; CAR + UV: carrageenan plus ultraviolet treatment; CHI + UV: chitosan plus ultraviolet treatment; UV + CAR: ultraviolet treatment plus carrageenan coating; UV + CHI: ultraviolet treatment plus chitosan coating.

7.0) containing $40 \mathrm{~g} / \mathrm{kg}$ of sucrose. The fixed samples were dehydrated in a graded ethanol series and embedded in hydroxyethyl methacrylate historesin. The obtained tissue blocks were sectioned at thickness of $\sim 20 \mu \mathrm{m}$ on a Leica SM 2000R microtome (Leica Microsystems, Heidelberg, Germany). The sectioned materials were stained with toluidine blue $(0.5 \mathrm{~g} / \mathrm{kg})$ in acetate buffer $(\mathrm{pH} 4.7)$ and the cell structures were observed under a Nikon Eclipse 80i light microscope (Nikon Instech Co., Ltd., Tokyo, Japan). For each treatment, five samples from different fruits were used for the observations.

2.16. Statistical Analysis. The experiments were performed in triplicate. The data was expressed as the means value and standard deviations. Minitab (v. 16.0) was used to perform analysis of variance (ANOVA). Significance differences between the means were set at a 5\% confidence level. Turkey test was chosen in the multiple comparisons' analysis.

\section{Results and Discussion}

3.1. Weight Loss. The water content of fruits and vegetables is a major factor in maintaining quality of horticultural produce. Low weight loss is important in maintaining the fruits quality over longer duration. Table 1 indicates a progressive weight loss of all samples during storage period, with maximum weight loss at the end of storage. Weight loss is associated with respiration and transpiration of moisture. According to Lin et al. [34], water loss in longan fruits was mainly from the pericarp rather than the aril (pulp). The water loss was also known to positively correlate with the pericarp browning of longan fruits $[34,35]$.

In this study, $\mathrm{CHI}+\mathrm{UV}$ and $\mathrm{UV}+\mathrm{CHI}$ treated fruits were noted to have relatively lower weight loss throughout storage days, as compared to CAR + UV and UV + CAR treatments; however, the differences were insignificant $(p>0.05)$ (Table 1). By day 7, the weight loss of UV + CHI and CHI + UV treated samples was 7.34 and $7.28 \%$, respectively, while that of $\mathrm{UV}+\mathrm{CAR}$ and CAR + UV treated fruits was 8.68 and $8.23 \%$, respectively. According to Abbasi et al. [36], the combinations of UV-C and edible coatings contributed to cell integrity and reduced fruit tissues' electrolyte leakage. Electrolyte leakage is related to membrane permeability and it gradually increases with ripening or aging. UV-C treatment might have induced biological stress and trigger defense mechanisms in plant materials. The initiation of polyamines accumulation in fruit tissue due to UV irradiation could prevent membrane damage. Chitosan or carrageenan coatings played the roles of reducing respiration rate by forming a semipermeable barrier against water vapors and gases and consequently retarded dehydration. This delayed senescence process helps to extend the shelf life of fruits $[36,37]$. Application of either treatment first on the fruits did not significantly $(p>0.05)$ affect weight loss (Table 1). Thus, it indicated that the sequence of treatments did not significantly $(p>0.05)$ impact on weight loss control. This was supported by results of coat homogeneity analysis (Figure 1) in which coat layer (chitosanor carrageenan-based coating) showed uniformity regardless of the coating that was applied before or after ultraviolet treatment. The ultraviolet light did not produce adverse effect on chitosan- or carrageenan-based coating.

3.2. Respiration Rate. Edible coating has the potential of reducing respiration rate of fruits. This is associated with a decrease in the metabolic rate. Reduction of the respiration rate as a result of coatings has been reported in coated fresh produce such as cherries [38], strawberry [39], and tangerine [40].

In this study, the respiration rates of all samples with different combinations of UV-C and edible coatings and sequences showed similar pattern. The respiration rate of longan fruits decreased in the first 3 days and then increased until the end of the storage day (Table 2). The increase in respiration at the end of shelf life can be correlated to the fruit's senescence process. However, there was no significant $(p>0.05)$ difference among all samples. The combinations of UV-C plus chitosan coating had similar respiration rate regardless of which treatment comes first, while for the combination of UV-C plus carrageenan coating, UV-C preceding coating exhibited insignificant $(p>0.05)$ higher respiration rate (Table 2).

3.3. Surface Lightness and Browning Index. Longan is easily susceptible to pericarp browning and color is a critical quality parameter during food purchases. During storage of the longan fruits in ambient temperature $\left(28^{\circ} \mathrm{C}\right)$, the coat color of the $\mathrm{UV}+\mathrm{CHI}$ or $\mathrm{CHI}+\mathrm{UV}$ treated fruits was significantly $(p<0.05)$ different from UV + CAR or CAR + UV treated fruits from the first day of storage. For instance, UV + CAR or CAR + UV treated fruits produced significantly $(p<0.05)$ higher surface lightness and significantly $(p<0.05)$ lower browning index than $\mathrm{UV}+\mathrm{CHI}$ or $\mathrm{CHI}+\mathrm{UV}$ treated fruits 
TABLE 2: The effect of different UV-C and edible coating combinations on respiration rate of longan fruits.

\begin{tabular}{lccrr}
\hline Treatment & \multicolumn{4}{c}{ Respiration rate $\left(\mathrm{ml} \mathrm{CO}_{2} / \mathrm{kg}^{\circ} \mathrm{h}\right)$} \\
Day 0 & Day 3 & Day 5 & Day 7 \\
\hline CAR + UV & $35.10 \pm 1.47^{\mathrm{a}, \mathrm{B}}$ & $20.08 \pm 0.99^{\mathrm{a}, \mathrm{C}}$ & $33.95 \pm 3.73^{\mathrm{a}, \mathrm{B}}$ & $55.83 \pm 4.03^{\mathrm{a}, \mathrm{A}}$ \\
$\mathrm{CHI}+\mathrm{UV}$ & $35.65 \pm 0.77^{\mathrm{a}, \mathrm{B}}$ & $20.78 \pm 2.94^{\mathrm{a}, \mathrm{C}}$ & $30.83 \pm 6.08^{\mathrm{a}, \mathrm{BC}}$ & $52.79 \pm 6.05^{\mathrm{a}, \mathrm{A}}$ \\
$\mathrm{UV}+\mathrm{CAR}$ & $33.60 \pm 2.53^{\mathrm{a}, \mathrm{BC}}$ & $23.39 \pm 2.76^{\mathrm{a}, \mathrm{C}}$ & $41.65 \pm 7.59^{\mathrm{a}, \mathrm{B}}$ & $61.90 \pm 1.50^{\mathrm{a}, \mathrm{A}}$ \\
$\mathrm{UV}+\mathrm{CHI}$ & $33.32 \pm 2.67^{\mathrm{a}, \mathrm{B}}$ & $21.51 \pm 1.33^{\mathrm{a}, \mathrm{C}}$ & $30.81 \pm 5.50^{\mathrm{a}, \mathrm{BC}}$ & $51.52 \pm 5.89^{\mathrm{a}, \mathrm{A}}$ \\
\hline
\end{tabular}

Different lowercase letter indicates significant difference at $p<0.05$ in each storage day; different uppercase letter indicates significant difference at $p<0.05$ in each treatment; CAR + UV: carrageenan plus ultraviolet treatment; CHI + UV: chitosan plus ultraviolet treatment; UV + CAR: ultraviolet treatment plus carrageenan coating; UV + CHI: ultraviolet treatment plus chitosan coating.

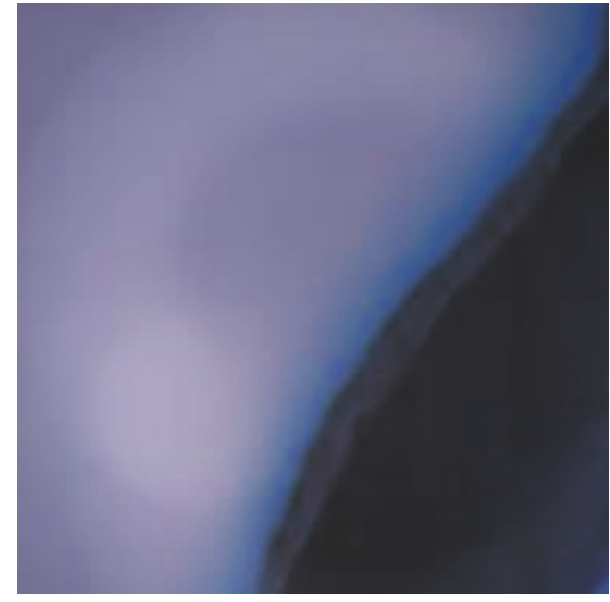

(a)

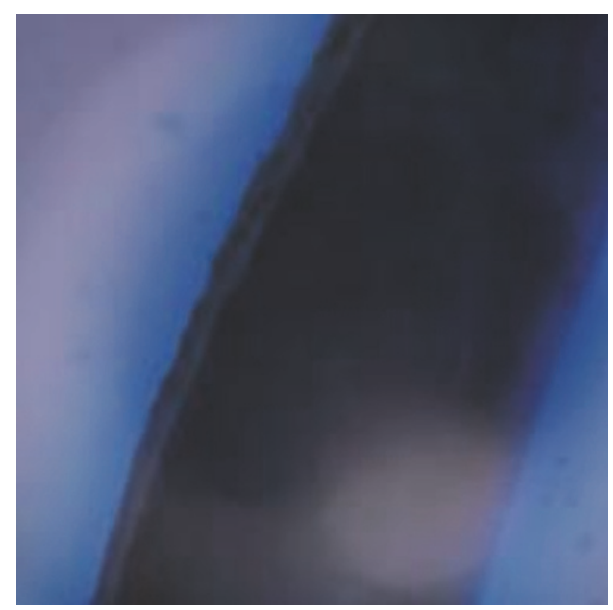

(c)

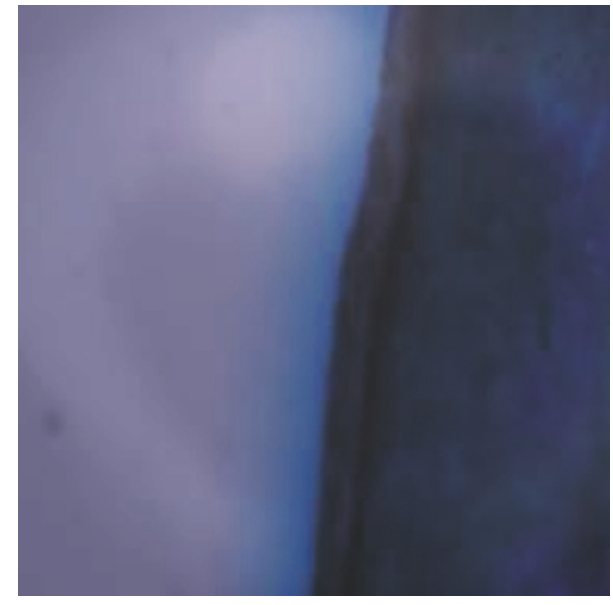

(b)

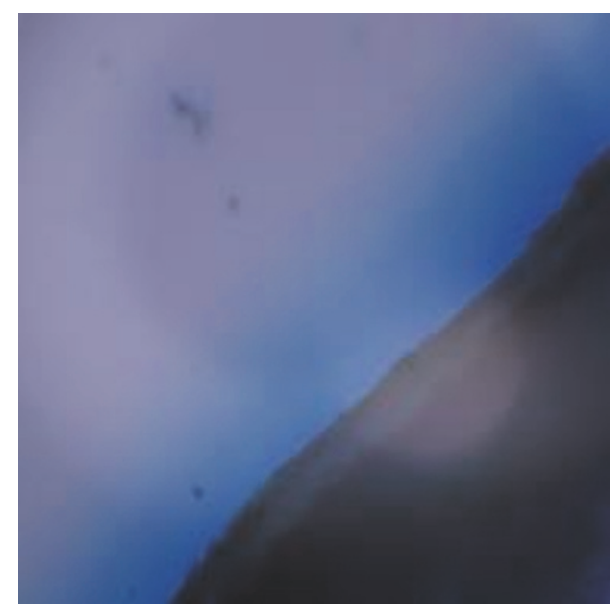

(d)

FIGURE 1: Micrograph of cross section of longan fruits treated by (a) UV irradiation followed by chitosan-based coating (UV + CHI), (b) UV irradiation followed by carrageenan-based coating (UV + CAR), (c) chitosan-based coating followed by UV irradiation (CHI + UV), and (d) carrageenan-based coating followed by UV irradiation (CAR + UV).

(Table 3). This is due to the effect of carrageenan coating which exhibits a higher lightness quality than chitosan. Casariego et al. [41] reported a 3\% decrease in lightness of film when there was a $1 \%$ increase in chitosan concentration. Opacity level of the carrageenan film was found to be $8.14 \%$ lower than that of the chitosan film when both films were compared in the same concentration [41, 42].
For the combination of UV-C and chitosan coating, the sequence of treatment does not impact any difference on the fruits. However, for the combination of UV-C and carrageenan coating, when UV-C preceded coating, its surface lightness was significantly $(p<0.05)$ decreased and the browning index was increased to a higher extent by the end of storage. 
TABLE 3: The effect of different UV-C and edible coating combinations on surface lightness and browning index of longan fruits.

\begin{tabular}{|c|c|c|c|c|c|}
\hline Parameter & Treatment & Day 0 & Day 3 & Day 5 & Day 7 \\
\hline \multirow{5}{*}{ Lightness } & $\mathrm{CAR}+\mathrm{UV}$ & $59.48 \pm 0.90^{\mathrm{a}, \mathrm{A}}$ & $56.44 \pm 1.28^{\mathrm{a}, \mathrm{AB}}$ & $56.40 \pm 0.63^{\mathrm{a}, \mathrm{AB}}$ & $53.89 \pm 1.67^{\mathrm{a}, \mathrm{B}}$ \\
\hline & $\mathrm{CHI}+\mathrm{UV}$ & $52.26 \pm 0.35^{\mathrm{b}, \mathrm{A}}$ & $49.29 \pm 0.76^{\mathrm{c}, \mathrm{AB}}$ & $49.13 \pm 1.89^{\mathrm{c}, \mathrm{AB}}$ & $48.46 \pm 1.59^{\mathrm{b}, \mathrm{B}}$ \\
\hline & $\mathrm{UV}+\mathrm{CAR}$ & $59.28 \pm 0.98^{\mathrm{a}, \mathrm{A}}$ & $56.28 \pm 1.03^{\mathrm{a}, \mathrm{A}}$ & $55.69 \pm 1.31^{\mathrm{ab}, \mathrm{A}}$ & $49.18 \pm 3.08^{\mathrm{ab}, \mathrm{B}}$ \\
\hline & $\mathrm{UV}+\mathrm{CHI}$ & $52.31 \pm 0.92^{\mathrm{b}, \mathrm{A}}$ & $49.40 \pm 1.07^{\mathrm{c}, \mathrm{AB}}$ & $49.19 \pm 1.30^{\mathrm{c}, \mathrm{AB}}$ & $47.88 \pm 1.44^{\mathrm{b}, \mathrm{B}}$ \\
\hline & Control & $53.94 \pm 0.48^{\mathrm{b}, \mathrm{A}}$ & $52.40 \pm 0.43^{\mathrm{b}, \mathrm{B}}$ & $52.42 \pm 0.78^{\mathrm{bc}, \mathrm{B}}$ & \\
\hline \multirow{5}{*}{ Browning index } & $\mathrm{CAR}+\mathrm{UV}$ & $15.45 \pm 1.68^{\mathrm{b}, \mathrm{A}}$ & $16.21 \pm 0.64^{\mathrm{b}, \mathrm{A}}$ & $16.26 \pm 0.61^{c, A}$ & $17.54 \pm 1.19^{\mathrm{b}, \mathrm{A}}$ \\
\hline & $\mathrm{CHI}+\mathrm{UV}$ & $20.42 \pm 1.12^{\mathrm{a}, \mathrm{A}}$ & $22.20 \pm 0.63^{\mathrm{a}, \mathrm{A}}$ & $22.23 \pm 0.69^{\mathrm{a}, \mathrm{A}}$ & $22.62 \pm 1.03^{\mathrm{a}, \mathrm{A}}$ \\
\hline & $\mathrm{UV}+\mathrm{CAR}$ & $16.32 \pm 1.29^{\mathrm{b}, \mathrm{B}}$ & $17.21 \pm 1.49^{\mathrm{b}, \mathrm{B}}$ & $17.27 \pm 1.06^{\mathrm{bc}, \mathrm{B}}$ & $21.94 \pm 2.71^{\mathrm{ab}, \mathrm{A}}$ \\
\hline & $\mathrm{UV}+\mathrm{CHI}$ & $20.86 \pm 2.00^{\mathrm{a}, \mathrm{A}}$ & $22.69 \pm 1.26^{\mathrm{a}, \mathrm{A}}$ & $22.79 \pm 1.33^{\mathrm{a}, \mathrm{A}}$ & $23.17 \pm 1.33^{\mathrm{a}, \mathrm{A}}$ \\
\hline & Control & $18.05 \pm 1.37^{\mathrm{ab}, \mathrm{A}}$ & $18.71 \pm 0.36^{\mathrm{b}, \mathrm{A}}$ & $18.69 \pm 0.12^{\mathrm{b}, \mathrm{A}}$ & \\
\hline
\end{tabular}

Different lowercase letter indicates significant difference at $p<0.05$ in each storage day; different uppercase letter indicates significant difference at $p<0.05$ in each treatment; CAR + UV: carrageenan plus ultraviolet treatment; CHI + UV: chitosan plus ultraviolet treatment; UV + CAR: ultraviolet treatment plus carrageenan coating; UV + CHI: ultraviolet treatment plus chitosan coating; control: fruits not subjected to coating or UV irradiation.

3.4. Polyphenol Oxidase (PPO) Activities. The effect of combination treatments of UV-C and edible coating in different sequences on PPO activities of longan pericarp and pulp is shown in Table 4. From the results, the PPO activities of both longan pericarp and longan pulp increased with the storage period. PPO is a copper-containing enzyme that is involved in the oxidation of phenolic in the presence of oxygen molecules, resulting in the formation of brown by-products [24]. In longan pericarp, UV + CHI treatment was observed to be the most effective in controlling PPO activities in longan pericarp. UV + CHI treated longan pericarp showed a significantly $(p<0.05)$ lower PPO activities compared to others on day 0 and day 5 , respectively (Table 4 ). A lower PPO activity is a reflection of reduced capacity for browning [43]. The results also showed that when UV-C precedes coating, PPO activities were delayed better. UV + CAR treated longan fruits had significantly $(p<0.05)$ lower PPO activity compared to CAR + UV treated fruits on day 3 and day 7, respectively. The differences obtained between the different treatment sequences might be attributed to the penetration depth of UV-C irradiation, which is limited to a thin layer and thus brings down the effectiveness of UV-C [44]. In between $\mathrm{UV}+\mathrm{CHI}$ and UV + CAR treated samples, the results showed that $\mathrm{UV}+\mathrm{CHI}$ treatment was more effective in controlling PPO activities; the PPO activity of $\mathrm{UV}+\mathrm{CHI}$ treated fruits was significantly $(p<0.05)$ lower compared to that of the UV + CAR treated fruits on day 0 and day 5. In UV + CHI treated fruits, chitosan contributed to the PPO activity inhibition as reported by Jiang et al. [24] and Zhang and Quantick [45]. Chitosan coating of either 1 or $2 \%$ contributed in controlling PPO activity.

In longan pulp, the PPO activity was much lower, which indicates that the browning was less likely to occur in the pulp. PPO activity of longan pulp as affected by different treatment sequences is shown in Table 4 . The UV $+\mathrm{CHI}$ treated longan pulp exhibited lower PPO activities than others throughout most of the storage days (Table 4). From these results, it is suggested that treatment of UV followed by chitosan coating tends to have a better effect on delaying browning.
3.5. Peroxidase (POD Activities). POD enzymes in plant tissues are usually referred to as guaiacol peroxidases (G-POD) and ascorbate peroxidases (AsA-POD) [46]. POD is a hemecontaining enzyme that performs single-electron oxidation of phenolic compounds in the presence of hydrogen peroxide. Hydrogen peroxide content in vegetable tissue is very low in nature. However, it is generated during the oxidation of phenolic catalyzed by polyphenol oxidase (PPO), which is involved in melanin formation that gives rise to pigments. Therefore, there is also the involvement of POD in browning processes [47].

Oxidation of many types of phenols in the presence of POD enzymes contributes to enzymatic browning of postharvest fruits such as litchi [30] and rambutan [48]. The effects of treatment combinations, such as UV-C exposure followed by edible coating in different sequences, on POD activity of longan pericarp and pulp are shown in Table 4. In longan pericarp, there was a slight increase in the POD activity. Throughout the storage days, the average increases in POD activity for each differently treated fruit were in a range of 1.8 to $3.7 \mathrm{U} / \mathrm{g}$ fw; the difference was small and showed no significant $(p>0.05)$ difference (Table 4$)$. In longan pulp, the POD activity was much lower than that in the pericarp, and the average increases of POD activity were also very slight, which were 0.04 to $0.08 \mathrm{U} / \mathrm{g}$ fw increment for differently treated longan fruits after 7 storage days (Table 4). Application of different UV-C and edible coating combinations and sequences had no significant $(p>0.05)$ effect on POD activity on both longan pericarp and longan pulp during the storage period (Table 4).

3.6. Phenylalanine Ammonia Lyase (PAL) Activities. The effect of different UV-C exposure and edible coating combinations and sequences on PAL activities of longan pericarp is shown in Table 4. Differences were found when the edible coating preceded the ultraviolet treatment. For combination of chitosan coating and ultraviolet treatment, $\mathrm{UV}+\mathrm{CHI}$ treated fruits maintained PAL at the same level with no significant $(p>0.05)$ increase while for CHI + UV treated fruits there was a significant $(p<0.05)$ increase in PAL on 
TABLE 4: The effect of different UV-C and edible coating combinations and sequences (together with control) on the TPC and enzymatic activities (PPO, POD, and PAL) of longan fruit pericarp and pulp.

\begin{tabular}{|c|c|c|c|c|c|c|}
\hline Treatment & & $\mathrm{CAR}+\mathrm{UV}$ & $\mathrm{CHI}+\mathrm{UV}$ & $\mathrm{UV}+\mathrm{CAR}$ & $\mathrm{UV}+\mathrm{CHI}$ & Control \\
\hline Day & & & & Longan pericarp & & \\
\hline 0 & \multirow{4}{*}{$\mathrm{PPO}^{*}$} & $124.87 \pm 4.74^{\mathrm{a}, \mathrm{D}}$ & $125.33 \pm 5.03^{\mathrm{a}, \mathrm{C}}$ & $125.40 \pm 2.78^{\mathrm{a}, \mathrm{C}}$ & $113.80 \pm 1.91^{\mathrm{b}, \mathrm{D}}$ & $131.07 \pm 1.94^{\mathrm{a}, \mathrm{C}}$ \\
\hline 3 & & $136.00 \pm 1.56^{\mathrm{b}, \mathrm{C}}$ & $134.60 \pm 0.40^{\mathrm{b}, \mathrm{B}}$ & $126.33 \pm 2.20^{\mathrm{c}, \mathrm{C}}$ & $122.33+2.05^{\mathrm{c}, \mathrm{C}}$ & $162.07 \pm 2.57^{\mathrm{a}, \mathrm{B}}$ \\
\hline 5 & & $154.33 \pm 2.37^{\mathrm{bc}, \mathrm{B}}$ & $157.73 \pm 1.01^{\mathrm{b}, \mathrm{A}}$ & $152.07 \pm 1.67^{\mathrm{c}, \mathrm{B}}$ & $142.47 \pm 0.46^{\mathrm{d}, \mathrm{B}}$ & $178.80 \pm 0.92^{\mathrm{a}, \mathrm{A}}$ \\
\hline 7 & & $168.13 \pm 2.61^{\mathrm{a}, \mathrm{A}}$ & $163.87 \pm 2.16^{\mathrm{ab}, \mathrm{A}}$ & $160.87 \pm 0.31^{\mathrm{b}, \mathrm{A}}$ & $163.33 \pm 0.70^{\mathrm{b}, \mathrm{A}}$ & - \\
\hline 0 & \multirow{4}{*}{$\mathrm{POD}^{*}$} & $20.31 \pm 2.17^{\mathrm{a}, \mathrm{A}}$ & $19.93 \pm 2.08^{\mathrm{a}, \mathrm{A}}$ & $18.99 \pm 2.13^{\mathrm{a}, \mathrm{A}}$ & $20.71 \pm 1.85^{\mathrm{a}, \mathrm{A}}$ & $23.82 \pm 1.86^{\mathrm{a}, \mathrm{C}}$ \\
\hline 3 & & $21.27 \pm 2.38^{\mathrm{b}, \mathrm{A}}$ & $22.49 \pm 2.78^{\mathrm{b}, \mathrm{A}}$ & $23.37 \pm 2.94^{\mathrm{b}, \mathrm{A}}$ & $21.03 \pm 1.43^{\mathrm{b}, \mathrm{A}}$ & $31.23 \pm 3.94^{\mathrm{a}, \mathrm{B}}$ \\
\hline 5 & & $20.27 \pm 2.38^{\mathrm{b}, \mathrm{A}}$ & $21.91 \pm 0.92^{\mathrm{b}, \mathrm{A}}$ & $22.27 \pm 3.47^{\mathrm{b}, \mathrm{A}}$ & $23.00 \pm 0.79^{\mathrm{b}, \mathrm{A}}$ & $39.33 \pm 1.93^{\mathrm{a}, \mathrm{A}}$ \\
\hline 7 & & $22.15 \pm 1.50^{\mathrm{a}, \mathrm{A}}$ & $23.59 \pm 2.42^{\mathrm{a}, \mathrm{A}}$ & $22.57 \pm 1.93^{\mathrm{a}, \mathrm{A}}$ & $23.91 \pm 0.31^{\mathrm{a}, \mathrm{A}}$ & - \\
\hline 0 & \multirow{4}{*}{$\mathrm{PAL}^{*}$} & $21.85 \pm 1.36^{\mathrm{b}, \mathrm{B}}$ & $20.90 \pm 0.47^{\mathrm{b}, \mathrm{B}}$ & $22.23 \pm 1.44^{\mathrm{b}, \mathrm{B}}$ & $22.04 \pm 1.03^{\mathrm{b}, \mathrm{A}}$ & $25.57 \pm 0.53^{\mathrm{a}, \mathrm{A}}$ \\
\hline 3 & & $23.41 \pm 1.61^{\mathrm{a}, \mathrm{B}}$ & $23.69 \pm 1.43^{\mathrm{a}, \mathrm{A}}$ & $23.64 \pm 0.26^{\mathrm{a}, \mathrm{B}}$ & $23.48 \pm 1.19^{\mathrm{a}, \mathrm{A}}$ & $26.22 \pm 0.45^{\mathrm{a}, \mathrm{A}}$ \\
\hline 5 & & $28.88 \pm 0.66^{\mathrm{a}, \mathrm{A}}$ & $23.91 \pm 0.45^{\mathrm{b}, \mathrm{A}}$ & $26.93 \pm 1.39^{\mathrm{a}, \mathrm{A}}$ & $23.87 \pm 0.81^{\mathrm{b}, \mathrm{A}}$ & $21.43 \pm 0.38^{c, B}$ \\
\hline 7 & & $30.98 \pm 0.85^{\mathrm{a}, \mathrm{A}}$ & $25.38 \pm 1.29^{\mathrm{bc}, \mathrm{A}}$ & $27.83 \pm 1.40^{\mathrm{ab}, \mathrm{A}}$ & $23.99 \pm 1.30^{\mathrm{c}, \mathrm{A}}$ & - \\
\hline 0 & \multirow{4}{*}{$\mathrm{TPC}^{\#}$} & $4.37 \pm 0.01^{\mathrm{bc}, \mathrm{A}}$ & $4.37 \pm 0.11^{\mathrm{bc}, \mathrm{A}}$ & $4.67 \pm 0.06^{\mathrm{a}, \mathrm{B}}$ & $4.55 \pm 0.09^{\mathrm{ab}, \mathrm{A}}$ & $4.17 \pm 0.10^{c, A}$ \\
\hline 3 & & $4.47 \pm 0.05^{\mathrm{bc}, \mathrm{A}}$ & $4.42 \pm 0.03^{\mathrm{c}, \mathrm{A}}$ & $5.00 \pm 0.07^{\mathrm{a}, \mathrm{A}}$ & $4.71 \pm 0.15^{\mathrm{b}, \mathrm{A}}$ & $3.93 \pm 0.13^{\mathrm{d}, \mathrm{A}}$ \\
\hline 5 & & $3.98 \pm 0.11^{\mathrm{ab}, \mathrm{B}}$ & $3.84 \pm 0.10^{\mathrm{b}, \mathrm{B}}$ & $4.20 \pm 0.14^{\mathrm{a}, \mathrm{C}}$ & $3.89 \pm 0.11^{\mathrm{ab}, \mathrm{B}}$ & $3.00 \pm 0.13^{c, B}$ \\
\hline \multirow[t]{2}{*}{7} & & $3.28 \pm 0.10^{\mathrm{bc}, \mathrm{C}}$ & $3.04 \pm 0.06^{\mathrm{c}, \mathrm{C}}$ & $3.87 \pm 0.03^{\mathrm{a}, \mathrm{D}}$ & $3.45 \pm 0.16^{\mathrm{b}, \mathrm{C}}$ & - \\
\hline & & & & LONGAN PULP & & \\
\hline 0 & \multirow{4}{*}{$\mathrm{PPO}^{*}$} & $28.33 \pm 3.08^{\mathrm{ab}, \mathrm{B}}$ & $30.93 \pm 1.50^{\mathrm{a}, \mathrm{B}}$ & $27.73 \pm 3.84^{\mathrm{ab}, \mathrm{C}}$ & $24.20 \pm 1.56^{\mathrm{b}, \mathrm{C}}$ & $28.16 \pm 1.12^{\mathrm{ab}, \mathrm{C}}$ \\
\hline 3 & & $29.93 \pm 0.42^{\mathrm{bc}, \mathrm{B}}$ & $32.20 \pm 0.72^{\mathrm{ab}, \mathrm{B}}$ & $28.87 \pm 1.29^{\mathrm{c}, \mathrm{BC}}$ & $29.20 \pm 0.53^{\mathrm{c}, \mathrm{BC}}$ & $33.12 \pm 1.05^{\mathrm{a}, \mathrm{B}}$ \\
\hline 5 & & $45.13 \pm 1.85^{\mathrm{a}, \mathrm{A}}$ & $42.73 \pm 0.99^{\mathrm{a}, \mathrm{A}}$ & $42.27 \pm 0.92^{\mathrm{a}, \mathrm{A}}$ & $36.53 \pm 2.57^{\mathrm{b}, \mathrm{A}}$ & $37.65 \pm 1.44^{\mathrm{b}, \mathrm{A}}$ \\
\hline 7 & & $38.80 \pm 5.17^{\mathrm{a}, \mathrm{A}}$ & $42.87 \pm 5.60^{\mathrm{a}, \mathrm{A}}$ & $37.20 \pm 5.44^{\mathrm{a}, \mathrm{AB}}$ & $34.20 \pm 2.82^{\mathrm{a}, \mathrm{AB}}$ & - \\
\hline 0 & \multirow{4}{*}{$\mathrm{POD}^{*}$} & $0.10 \pm 0.00^{\mathrm{b}, \mathrm{B}}$ & $0.11 \pm 0.01^{\mathrm{b}, \mathrm{B}}$ & $0.09 \pm 0.01^{\mathrm{b}, \mathrm{B}}$ & $0.09 \pm 0.01^{\mathrm{b}, \mathrm{B}}$ & $0.17 \pm 0.03^{\mathrm{a}, \mathrm{C}}$ \\
\hline 3 & & $0.11 \pm 0.01^{\mathrm{b}, \mathrm{B}}$ & $0.13 \pm 0.01^{\mathrm{b}, \mathrm{B}}$ & $0.10 \pm 0.02^{\mathrm{b}, \mathrm{AB}}$ & $0.11 \pm 0.01^{\mathrm{b}, \mathrm{AB}}$ & $0.27 \pm 0.03^{\mathrm{a}, \mathrm{B}}$ \\
\hline 5 & & $0.13 \pm 0.01^{\mathrm{b}, \mathrm{B}}$ & $0.13 \pm 0.01^{\mathrm{b}, \mathrm{B}}$ & $0.11 \pm 0.01^{\mathrm{b}, \mathrm{AB}}$ & $0.12 \pm 0.02^{\mathrm{b}, \mathrm{AB}}$ & $0.37 \pm 0.03^{\mathrm{a}, \mathrm{A}}$ \\
\hline 7 & & $0.19 \pm 0.03^{\mathrm{a}, \mathrm{A}}$ & $0.19 \pm 0.03^{\mathrm{a}, \mathrm{A}}$ & $0.13 \pm 0.01^{\mathrm{a}, \mathrm{A}}$ & $0.15 \pm 0.01^{\mathrm{a}, \mathrm{A}}$ & - \\
\hline 0 & \multirow{4}{*}{$\mathrm{PAL}^{*}$} & $2.42 \pm 0.11^{\mathrm{ab}, \mathrm{A}}$ & $2.50 \pm 0.11^{\mathrm{ab}, \mathrm{A}}$ & $2.38 \pm 0.14^{\mathrm{b}, \mathrm{A}}$ & $2.43 \pm 0.20^{\mathrm{ab}, \mathrm{A}}$ & $2.77 \pm 0.13^{\mathrm{a}, \mathrm{A}}$ \\
\hline 3 & & $2.49 \pm 0.48^{\mathrm{a}, \mathrm{A}}$ & $2.53 \pm 0.46^{\mathrm{a}, \mathrm{A}}$ & $2.38 \pm 0.12^{\mathrm{a}, \mathrm{A}}$ & $2.51 \pm 0.22^{\mathrm{a}, \mathrm{A}}$ & $2.77 \pm 0.21^{\mathrm{a}, \mathrm{A}}$ \\
\hline 5 & & $2.49 \pm 0.29^{\mathrm{a}, \mathrm{A}}$ & $2.51 \pm 0.05^{\mathrm{a}, \mathrm{A}}$ & $2.55 \pm 0.30^{\mathrm{a}, \mathrm{A}}$ & $2.53 \pm 0.29^{\mathrm{a}, \mathrm{A}}$ & $2.77 \pm 0.24^{\mathrm{a}, \mathrm{A}}$ \\
\hline 7 & & $2.95 \pm 0.19^{\mathrm{a}, \mathrm{A}}$ & $2.81 \pm 0.08^{\mathrm{a}, \mathrm{A}}$ & $2.87 \pm 0.18^{\mathrm{a}, \mathrm{A}}$ & $2.81 \pm 0.34^{\mathrm{a}, \mathrm{A}}$ & - \\
\hline 0 & \multirow{4}{*}{$\mathrm{TPC}^{\#}$} & $0.72 \pm 0.02^{\mathrm{ab}, \mathrm{B}}$ & $0.75 \pm 0.02^{\mathrm{a}, \mathrm{B}}$ & $0.74 \pm 0.03^{\mathrm{ab}, \mathrm{B}}$ & $0.74 \pm 0.01^{\mathrm{ab}, \mathrm{B}}$ & $0.67 \pm 0.05^{\mathrm{b}, \mathrm{B}}$ \\
\hline 3 & & $0.82 \pm 0.05^{\mathrm{a}, \mathrm{AB}}$ & $0.81 \pm 0.03^{\mathrm{a}, \mathrm{AB}}$ & $0.83 \pm 0.05^{\mathrm{a}, \mathrm{AB}}$ & $0.80 \pm 0.07^{\mathrm{a}, \mathrm{AB}}$ & $0.78 \pm 0.04^{\mathrm{a}, \mathrm{A}}$ \\
\hline 5 & & $0.81 \pm 0.05^{\mathrm{a}, \mathrm{AB}}$ & $0.81 \pm 0.02^{\mathrm{a}, \mathrm{AB}}$ & $0.86 \pm 0.04^{\mathrm{a}, \mathrm{A}}$ & $0.81 \pm 0.03^{\mathrm{a}, \mathrm{AB}}$ & $0.81 \pm 0.02^{\mathrm{a}, \mathrm{A}}$ \\
\hline 7 & & $0.88 \pm 0.01^{\mathrm{a}, \mathrm{A}}$ & $0.85 \pm 0.05^{\mathrm{a}, \mathrm{A}}$ & $0.90 \pm 0.02^{\mathrm{a}, \mathrm{A}}$ & $0.88 \pm 0.03^{\mathrm{a}, \mathrm{A}}$ & - \\
\hline
\end{tabular}

Different lowercase letter indicates significant difference at $p<0.05$ in each storage day within PPO, POD, PAL, or TPC in longan fruit pericarp or pulp; different uppercase letter indicates significant difference at $p<0.05$ in each treatment within PPO, POD, PAL, or TPC in longan fruit pericarp or pulp; *: activity (U/g fw); \#: content (mg/g GAE fw); CAR: carrageenan; CHI: chitosan; UV: ultraviolet-treated; PPO: polyphenol oxidase; POD: peroxidase; PAL: phenylalanine ammonia lyase; TPC: total phenolic content; control: fruits not subjected to coating or UV irradiation.

day 3 (Table 4). From the first day of treatment till the end of storage day, there was only an average increase of $1.95 \mathrm{U} / \mathrm{g}$ fw PAL activities for UV + CHI treated fruits while $4.48 \mathrm{U} / \mathrm{g}$ fw for CHI + UV treated fruits (Table 4). In the case of carrageenan coating and ultraviolet treatment, UV + CAR treated fruits exhibited relatively smaller increases in PAL activity compared to CAR + UV treated fruits throughout storage, although the difference was not significant $(p>0.05)$ (Table 4). The average increases of PAL activity throughout storage were 5.60 and $9.13 \mathrm{U} / \mathrm{g}$ fw for $\mathrm{UV}+\mathrm{CAR}$ and CAR + $\mathrm{UV}$, respectively (Table 4). Among all treatments, it is suggested that UV + CHI treatment was better as it showed that UV + CHI was able to maintain PAL activity at the same level while the rest treatments showed a relatively bigger fluctuation during storage period. PAL plays a significant role in browning as the $\mathrm{O}$-diphenols formed during the phenylpropanoids' pathway can be oxidized by PPO and polymerized into melanin pigments [47]. Thus, repressing induction of PAL activity could also inhibit browning.

In longan pulp, the result of the effect of different UV$\mathrm{C}$ and edible coating combinations and sequences on PAL activity is shown in Table 4 . The effect of different combinations and sequences of treatment produced very little difference; the changes of PAL activity throughout storage were from 0.31 to $0.53 \mathrm{U} / \mathrm{g}$ fw.

3.7. Total Phenolic Contents (TPC). The TPC initially exhibited a slight increase in all treated fruits between day 0 and day 
3 of storage. However, this trend was followed by significant decreases $(p<0.05)$ from day 5 through day 7 (Table 4$)$. The increase in TPC in samples was probably due to the release of phenolic compounds from glycosidic compounds and the degradation of larger phenolic compounds to smaller one by UV-C irradiation [20,49]. In addition, higher TPC might be due to the induction of phenolic biosynthesis which occurred under stress conditions such as excessive UV light, wounding, or pathogen infection [50]. The response to UVC irradiation served as a defense mechanism in plants [51]. During storage, the decrease in TPC in all treatments is attributed to oxidation of phenolic compounds catalyzed by polyphenol oxidase (PPO). There was an enhanced activity of PPO along postharvest storage as a result of senescence process or solubilisation of cell wall pectic substances leading to the destruction of biological barrier between PPO and polyphenols [20]. The PPO enzyme is active when it unites with its phenolic substrates.

It is known that UV-C irradiation as well as edible coating treatment has inhibitory effect on the rates of respiration and senescence which is responsible for oxidative breakdown of phenolic; thus the combination of either chitosan or carrageenan coating and UV-C irradiation was able to retain a higher level of TPC [20]. From the results shown in Table 4, $\mathrm{UV}+\mathrm{CAR}$ and $\mathrm{UV}+\mathrm{CHI}$ treated longan pericarp tends to trigger and retain higher TPC than CAR + UV and CHI + UV fruits during the storage. In addition, UV + CAR treated fruits were significantly $(p<0.05)$ higher in TPC on days 0 and 3 while UV $+\mathrm{CHI}$ treated fruits showed no significant $(p>0.05)$ difference in TPC (Table 4). By the end of storage days, the average retained TPC in the $\mathrm{UV}+\mathrm{CHI}$ treated fruit pericarp was $13.49 \%$ higher than that in the $\mathrm{CHI}+$ UV treated fruit pericarp while in UV + CAR treated fruit pericarp the average retained TPC was $17.99 \%$ higher than that in the CAR + UV treated fruit pericarp (Table 4). The most effective treatment was when UV-C preceded coating in longan pericarp. The probable reason for this might be attributed to the direct exposure of UV light on to the fruits.

In longan pulp, the results of the effect of the different treatment combinations and sequences on TPC are shown in Table 4. Total phenolic content exhibited only slight increase throughout storage in all treatments. In this context, different treatments and their sequence and storage time had a positive effect on TPC of longan flesh. The increase of TPC throughout storage has also been reported in some fruits such as UV-C treated strawberries [46], guava [12], banana [12], or edible coated plus gamma irradiated strawberries [20].

3.8. Coat Homogeneity. Micrographs of cross section of the coated samples are shown in Figure 1. When coating materials were applied on fruits, two forces are brought to the fore: (1) cohesion of the molecules within the coating and (2)adhesion between the coating and fruit. The degree of cohesion of the coating governs barrier and mechanical properties of the coating. The stronger the barrier properties of the film, the higher the degree of cohesion. This also leads to a lower flexibility of the film [52]. There was a remarkable homogeneity between the chitosan- and carrageenan-coated longan fruits.
The coatings covered the whole surface of longan fruits and showed good adherence. The determined thickness of coating showed insignificant difference $(p>0.05)$ for the same coating in different sequences. The obtained coating thickness values were $21.22 \pm 2.25 \mu \mathrm{m}$ for $\mathrm{UV}+\mathrm{CHI}$ treated fruits and $21.79 \pm 2.23 \mu \mathrm{m}$ for CHI + UV treated fruits while those for $\mathrm{UV}+\mathrm{CAR}$ treated fruits and CAR + UV treated fruits were $56.53 \pm 6.33 \mu \mathrm{m}$ and $53.24 \pm 5.16 \mu \mathrm{m}$, respectively.

3.9. Microscopic Analysis. Microscopic observations were carried out on longan fruits which were differently treated and compared to untreated longan fruits. Figure 2 shows micrographs of the cellular structure of the treated and untreated longan fruits on days 2 and 7 of storage. On the 2nd day of storage, treated and untreated longan flesh were quite similar (Figures 2(a), 2(c), 2(e), 2(g), and 2(i)); they had turgid cells and the cells were round, well-defined, and slightly folded (Figures 2(a), 2(c), 2(e), 2(g), and 2(i)). The light plasmolysis and shape alteration were demonstrated by the dashed arrows.

When the treated and untreated fruits were examined on day 7 (Figures 2(b), 2(d), 2(f), 2(h), and 2(j)), it can be seen that the plasmolysis and cell wall alteration were more severe compared to day 2 . The cellular plasmolysis and loss of cell turgor pressure were probably due to weight loss [33]. In controlled fruits, the structure contained more deformed, contracted, collapsed, and damaged cells (Figure 2(b)). It had more damaged cell walls (shown by solid arrows) and led to alteration in cell wall components. In the rest of the samples (Figures 2(d), 2(f), 2(h), and 2(j)), the structural damage was less, especially UV $+\mathrm{CHI}$ treated fruit, which showed a more structured cell arrangement (Figure 2(d)).

Besides, an increase in intercellular spaces and a reduction in contacts between cells can be observed in the samples on day 7 (Figures 2(b), 2(d), 2(f), 2(h), and 2(j)) compared to day 2 (Figures 2(a), 2(c), 2(e), 2(g), and 2(i)). In UV + CAR treated sample, the separation of some cells and loss of adhesion between adjacent cell walls were more severe than others (Figure 2(h)). Increasing of intercellular spaces was linked to the senescence process as it facilitated the penetration of microorganisms into cells.

\section{Conclusions}

This study has shown that when UV was applied before coating (i.e., both chitosan and carrageenan), there was a relatively lower PPO and PAL activities with a higher TPC retention in longan pericarp. However, these enzymatic activities' changes did not impart on the surface lightness and browning index as they were more influenced by type of coating, in which combination treatments consisting of carrageenan showed higher surface lightness and lower browning index compared to combination treatments consisting of chitosan coating due to the natural color of the coating materials.

When UV treatment preceded coating, the effect was greater for combinations of UV plus chitosan coating than for UV plus carrageenan. UV plus chitosan coating showed significantly lower PPO (pericarp and pulp) and PAL (pericarp) 


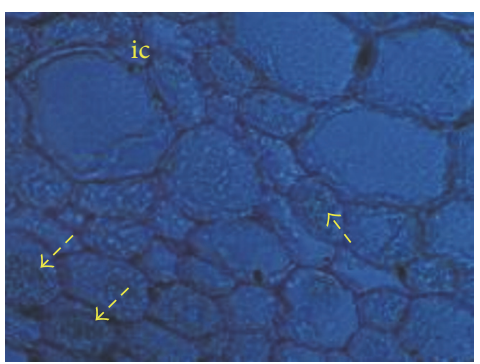

(a)

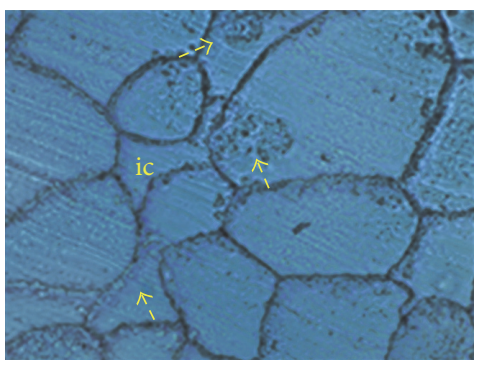

(d)

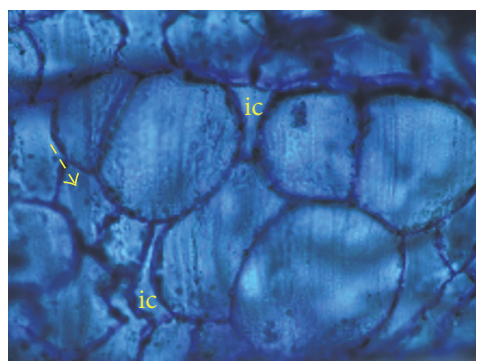

(g)

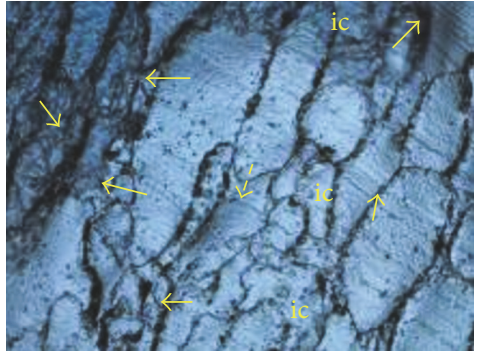

(b)

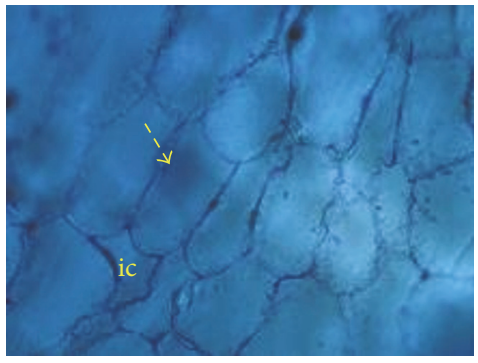

(e)

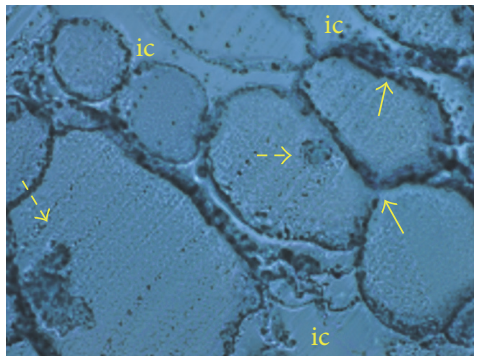

(h)

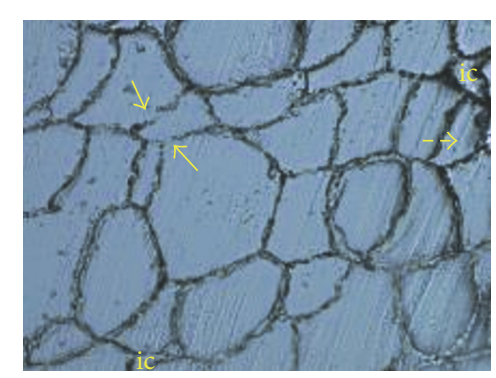

(j)

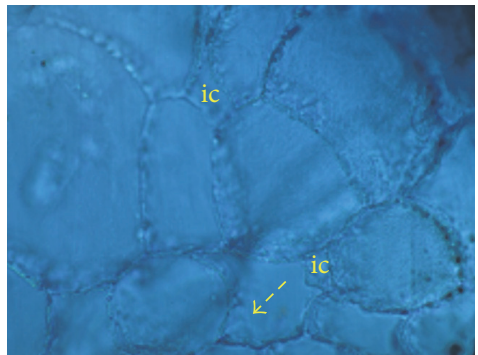

(c)

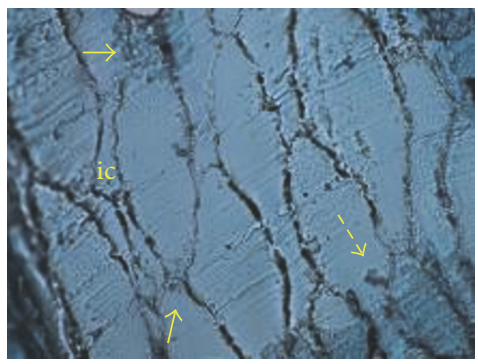

(f)

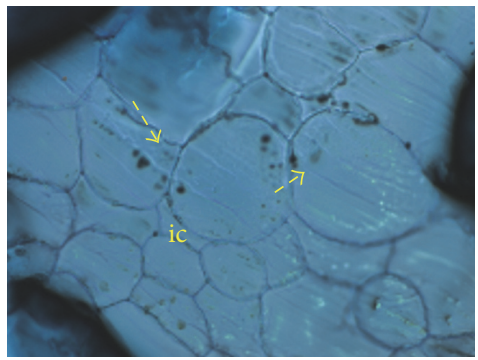

(i)

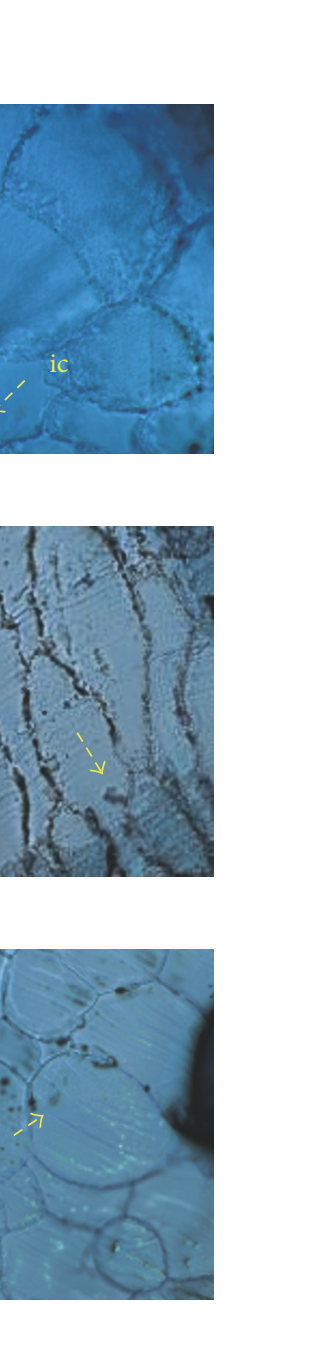




\section{Conflicts of Interest}

The authors declare that they have no conflicts of interest.

\section{Acknowledgments}

The authors are grateful for the extensive financial support of the Grant Putra IPS (GP-IPS/2016/9478500) at the Universiti Putra Malaysia.

\section{References}

[1] M. M. Wall, "Ascorbic acid and mineral composition of longan (Dimocarpus longan), lychee (Litchi chinensis) and rambutan (Nephelium lappaceum) cultivars grown in Hawaii," Journal of Food Composition and Analysis, vol. 19, no. 6-7, pp. 655-663, 2006.

[2] B. Yang, Y. Jiang, J. Shi, F. Chen, and M. Ashraf, "Extraction and pharmacological properties of bioactive compounds from longan (Dimocarpus longan Lour.) fruit-a review," Food Research International, vol. 44, no. 7, pp. 1837-1842, 2011.

[3] S. J. Chen, J. Q. Chen, Q. Z. Hong, and H. T. Lin, "Current situation and advances in post-harvest storage and transportation technologies of longan fruit," in International Symposium on Litchi and Longan, vol. 558, pp. 343-351, 2000.

[4] X. Q. Pan and Z. Q. Zhang, "dvances in postharvest physiology and technology for storage of longan fruit," Tropical Agricultural Science, vol. 27, pp. 56-59, 1999.

[5] Y. Jiang, "The use of microbial metabolites against post-harvest diseases of longan fruit," International Journal of Food Science \& Technology, vol. 32, no. 6, pp. 535-538, 1997.

[6] Y. Jiang, Z. Zhang, D. C. Joyce, and S. Ketsa, "Postharvest biology and handling of longan fruit (Dimocarpus longan Lour.)," Postharvest Biology and Technology, vol. 26, no. 3, pp. 241-252, 2002.

[7] C. Sodchit, T. Kongbangkerd, and W. N. Phun, "Prevention of enzymatic browning of postharvest longan fruit by $\mathrm{N}$-acetylL-cysteine and 4-hexylresorcinol," Songklanakarin Journal of Science and Technology, vol. 30, no. 1, pp. 31-35, 2008.

[8] C. Alegria, J. Pinheiro, M. Duthoit, E. M. Gonçalves, M. Moldão-Martins, and M. Abreu, "Fresh-cut carrot (cv. Nantes) quality as affected by abiotic stress (heat shock and UV-C irradiation) pre-treatments," LWT-Food Science and Technology, vol. 48, no. 2, pp. 197-203, 2012.

[9] L. S. Teoh, O. Lasekan, N. M. Adzahan, and N. Hashim, "The effect of ultraviolet treatment on enzymatic activity and total phenolic content of minimally processed potato slices," Journal of Food Science and Technology, vol. 53, no. 7, pp. 3035-3042, 2016.

[10] M. Turtoi, "Ultraviolet light treatment of fresh fruits and vegetables surface: a review," Journal of Agroalimentary Processes and Technologies, vol. 19, no. 3, pp. 325-337, 2013.

[11] E. A. Barka, S. Kalantari, J. Makhlouf, and J. Arul, "Impact of UV-C irradiation on the cell wall-degrading enzymes during ripening of tomato (Lycopersicon esculentum L.) fruit," Journal of Agricultural and Food Chemistry, vol. 48, no. 3, pp. 667-671, 2000.

[12] M. Alothman, R. Bhat, and A. A. Karim, "UV radiation-induced changes of antioxidant capacity of fresh-cut tropical fruits," Innovative Food Science and Emerging Technologies, vol. 10, no. 4, pp. 512-516, 2009.
[13] N. Basaran, A. Quintero-Ramos, M. M. Moake, J. J. Churey, and R. W. Worobo, "Influence of apple cultivars on inactivation of different strains of Escherichia coli O157:H7 in apple cider by UV irradiation," Applied and Environmental Microbiology, vol. 70, no. 10, pp. 6061-6065, 2004.

[14] D. J. Geveke, "Uv inactivation of E. coli in liquid egg white," Food and Bioprocess Technology, vol. 1, no. 2, pp. 201-206, 2008.

[15] K. E. Matak, J. J. Churey, R. W. Worobo et al., "Efficacy of UV light for the reduction of Listeria monocytogenes in goat's milk," Journal of Food Protection, vol. 68, no. 10, pp. 2212-2216, 2005.

[16] R. K. Dhall, "Advances in edible coatings for fresh fruits and vegetables: a review," Critical Reviews in Food Science and Nutrition, vol. 53, no. 5, pp. 435-450, 2013.

[17] K. N. Turhan, "Is edible coating an alternative to MAP for fresh and minimally processed fruits?" X International Controlled and Modified Atmosphere Research Conference, vol. 876, pp. 299305, 2009.

[18] E. Ayranci and S. Tunc, "A method for the measurement of the oxygen permeability and the development of edible films to reduce the rate of oxidative reactions in fresh foods," Food Chemistry, vol. 80, no. 3, pp. 423-431, 2003.

[19] D. Marquenie, C. W. Michiels, A. H. Geeraerd et al., "Using survival analysis to investigate the effect of UV-C and heat treatment on storage rot of strawberry and sweet cherry," International Journal of Food Microbiology, vol. 73, no. 2-3, pp. 187-196, 2002.

[20] P. R. Hussain, M. A. Dar, and A. M. Wani, "Effect of edible coating and gamma irradiation on inhibition of mould growth and quality retention of strawberry during refrigerated storage," International Journal of Food Science and Technology, vol. 47, no. 11, pp. 2318-2324, 2012.

[21] P. M. Freitas, F. López-Gálvez, J. A. Tudela, M. I. Gil, and A. Allende, "Postharvest treatment of table grapes with ultraviolet$\mathrm{C}$ and chitosan coating preserves quality and increases stilbene content," Postharvest Biology and Technology, vol. 105, pp. 51-57, 2015.

[22] P. L. Gómez, S. M. Alzamora, M. A. Castro, and D. M. Salvatori, "Effect of ultraviolet-C light dose on quality of cut-apple: Microorganism, color and compression behavior," Journal of Food Engineering, vol. 98, no. 1, pp. 60-70, 2010.

[23] J.-H. Jang and K.-D. Moon, "Inhibition of polyphenol oxidase and peroxidase activities on fresh-cut apple by simultaneous treatment of ultrasound and ascorbic acid," Food Chemistry, vol. 124, no. 2, pp. 444-449, 2011.

[24] Y. Jiang, J. Li, and W. Jiang, "Effects of chitosan coating on shelf life of cold-stored litchi fruit at ambient temperature," LWT_Food Science and Technology, vol. 38, no. 7, pp. 757-761, 2005.

[25] C. Ribeiro, A. A. Vicente, J. A. Teixeira, and C. Miranda, "Optimization of edible coating composition to retard strawberry fruit senescence," Postharvest Biology and Technology, vol. 44, no. 1, pp. 63-70, 2007.

[26] N. Azarakhsh, A. Osman, H. M. Ghazali, C. P. Tan, and N. Mohd Adzahan, "Optimization of alginate and gellan-based edible coating formulations for fresh-cut pineapples," International Food Research Journal, vol. 19, no. 1, pp. 279-285, 2012.

[27] H. M. Hamzah, A. Osman, C. P. Tan, and F. Mohamad Ghazali, "Carrageenan as an alternative coating for papaya (Carica papaya L. cv. Eksotika)," Postharvest Biology and Technology, vol. 75, pp. 142-146, 2013.

[28] X. Duan, X. Su, Y. You, H. Qu, Y. Li, and Y. Jiang, "Effect of nitric oxide on pericarp browning of harvested longan fruit in 
relation to phenolic metabolism," Food Chemistry, vol. 104, no. 2, pp. 571-576, 2007.

[29] Y. Jiang, "Role of anthocyanins, polyphenol oxidase and phenols in lychee pericarp browning," Journal of the Science of Food and Agriculture, vol. 80, no. 3, pp. 305-310, 2000.

[30] Z. Zhang, X. Pang, D. Xuewu, Z. Ji, and Y. Jiang, "Role of peroxidase in anthocyanin degradation in litchi fruit pericarp," Food Chemistry, vol. 90, no. 1-2, pp. 47-52, 2005.

[31] Y. Jiang and D. C. Joyce, "ABA effects on ethylene production, PAL activity, anthocyanin and phenolic contents of strawberry fruit," Plant Growth Regulation, vol. 39, no. 2, pp. 171-174, 2003.

[32] V. L. Singleton and J. A. Rossi, "Colorimetry of total phenolic with phosphomolybdic-phosphotungstic acid reagents," American Journal of Enology and Viticulture, vol. 16, no. 3, pp. 144-158, 1965.

[33] C. C. Ferrari, C. I. G. L. Sarantópoulos, S. M. CarmelloGuerreiro, and M. D. Hubinger, "Effect of osmotic dehydration and pectin edible coatings on quality and shelf life of fresh-cut melon," Food and Bioprocess Technology, vol. 6, no. 1, pp. 80-91, 2013.

[34] H. Lin, S. Chen, Y. S. Guo, Y. Xi, and S. Guo, "Observation on pericarp ultrastructure by scanning electron microscope and its relation to keeping quality of longan fruit," Transactions of the Chinese Society of Agricultural Engineering, vol. 18, no. 3, pp. 9599, 2001.

[35] H. T. Lin, Y. F. S. J. Chen, Y. F. Xi, and S. J. Chen, "The relationship between the desiccation-induced browning and the metabolism of active oxygen and phenolics in pericarp of postharvest longan fruit," Journal of Plant Physiology and Molecular Biology, vol. 31, no. 3, pp. 287-297, 2005.

[36] N. A. Abbasi, S. Ashraf, I. Ali, and S. J. Butt, "Enhancing storage life of bell pepper by UV-C irradiation and edible coatings," Pakistan Journal of Agricultural Sciences, vol. 52, no. 2, pp. 403411, 2015.

[37] Y. Ni, D. Turner, K. M. Yates, and I. Tizard, "Isolation and characterization of structural components of Aloe vera L. leaf pulp," International Immunopharmacology, vol. 4, no. 14, pp. 1745-1755, 2004.

[38] D. Martínez-Romero, N. Alburquerque, J. M. Valverde et al., "Postharvest sweet cherry quality and safety maintenance by Aloe vera treatment: a new edible coating," Postharvest Biology and Technology, vol. 39, no. 1, pp. 93-100, 2006.

[39] A. El Ghaouth, J. Arul, R. Ponnampalam, and M. Boulet, "Chitosan coating effect on storability and quality of fresh strawberries," Journal of Food Science, vol. 56, no. 6, pp. 16181631, 1991.

[40] P. Seehanam, D. Boonyakiat, and N. Rattanapanone, "Physiological and physicochemical responses of 'Sai nam phueng' tangerine to commercial coatings," HortScience, vol. 45, no. 4, pp. 605-609, 2010.

[41] A. Casariego, B. W. S. Souza, M. A. Cerqueira et al., "Chitosan/clay films' properties as affected by biopolymer and clay micro/nanoparticles' concentrations," Food Hydrocolloids, vol. 23, no. 7, pp. 1895-1902, 2009.

[42] S. He, Y. Wang, Y. Sun, S. Chen, Y. Zhang, and M. Ying, "Antimicrobial activity and preliminary characterization of $\kappa$ carrageenan films containing cinnamon essential oil," Advance Journal of Food Science and Technology, vol. 9, no. 7, pp. 523-528, 2015.

[43] W. Chitbanchong, V. Sardsud, K. Whangchai, R. Koslanund, and P. Thobunluepop, "Minimally of polyphenol oxidase activity and controlling of rotting and browning of longan fruits cv. DAW by SO2 treatment under cold storage conditions," International Journal of Agricultural Research, vol. 4, no. 11, pp. 349-361, 2009.

[44] L. Manzocco, S. Da Pieve, A. Bertolini et al., "Surface decontamination of fresh-cut apple by UV-C light exposure: effects on structure, colour and sensory properties," Postharvest Biology and Technology, vol. 61, no. 2, pp. 165-171, 2011.

[45] D. Zhang and P. C. Quantick, "Effects of chitosan coating on enzymatic browning and decay during postharvest storage of litchi (Litchi chinensis Sonn.) fruit," Postharvest Biology and Technology, vol. 12, no. 2, pp. 195-202, 1997.

[46] M. Erkan, S. Y. Wang, and C. Y. Wang, "Effect of UV treatment on antioxidant capacity, antioxidant enzyme activity and decay in strawberry fruit," Postharvest Biology and Technology, vol. 48, no. 2, pp. 163-171, 2008.

[47] R. González-Barrio, M. Salmenkallio-Marttila, F. A. TomásBarberán, E. Cantos, and J. C. Espín, "Etiology of UV-Cinduced browning in var. Superior white table grapes," Journal of Agricultural and Food Chemistry, vol. 53, no. 15, pp. 5990-5996, 2005.

[48] P. Yingsanga, V. Srilaong, S. Kanlayanarat, S. Noichinda, and W. B. McGlasson, "Relationship between browning and related enzymes (PAL, PPO and POD) in rambutan fruit (Nephelium lappaceum Linn.) cvs. Rongrien and See-Chompoo," Postharvest Biology and Technology, vol. 50, no. 2-3, pp. 164-168, 2008.

[49] D. Štajner, M. Milošević, and B. M. Popović, "Irradiation effects on phenolic content, lipid and protein oxidation and scavenger ability of soybean seeds," International Journal of Molecular Sciences, vol. 8, no. 7, pp. 618-627, 2007.

[50] Q. Wang, Y. Cao, L. Zhou, C.-Z. Jiang, Y. Feng, and S. Wei, "Effects of postharvest curing treatment on flesh colour and phenolic metabolism in fresh-cut potato products," Food Chemistry, vol. 169, pp. 246-254, 2015.

[51] L. S. Teoh, O. Lasekan, N. M. Adzahan, and N. Hashim, "The effect of combinations of UV-C exposure with ascorbate and calcium chloride dips on the enzymatic activities and total phenolic content of minimally processed yam slices," Postharvest Biology and Technology, vol. 120, pp. 138-144, 2016.

[52] S. Guilbert and B. Biquet, "Edible films and coatings," in Food Packaging Technology, G. Bureau and J. L. Multon, Eds., pp. 315316, VCH Publishers Inc, New York, NY, USA, 1996. 

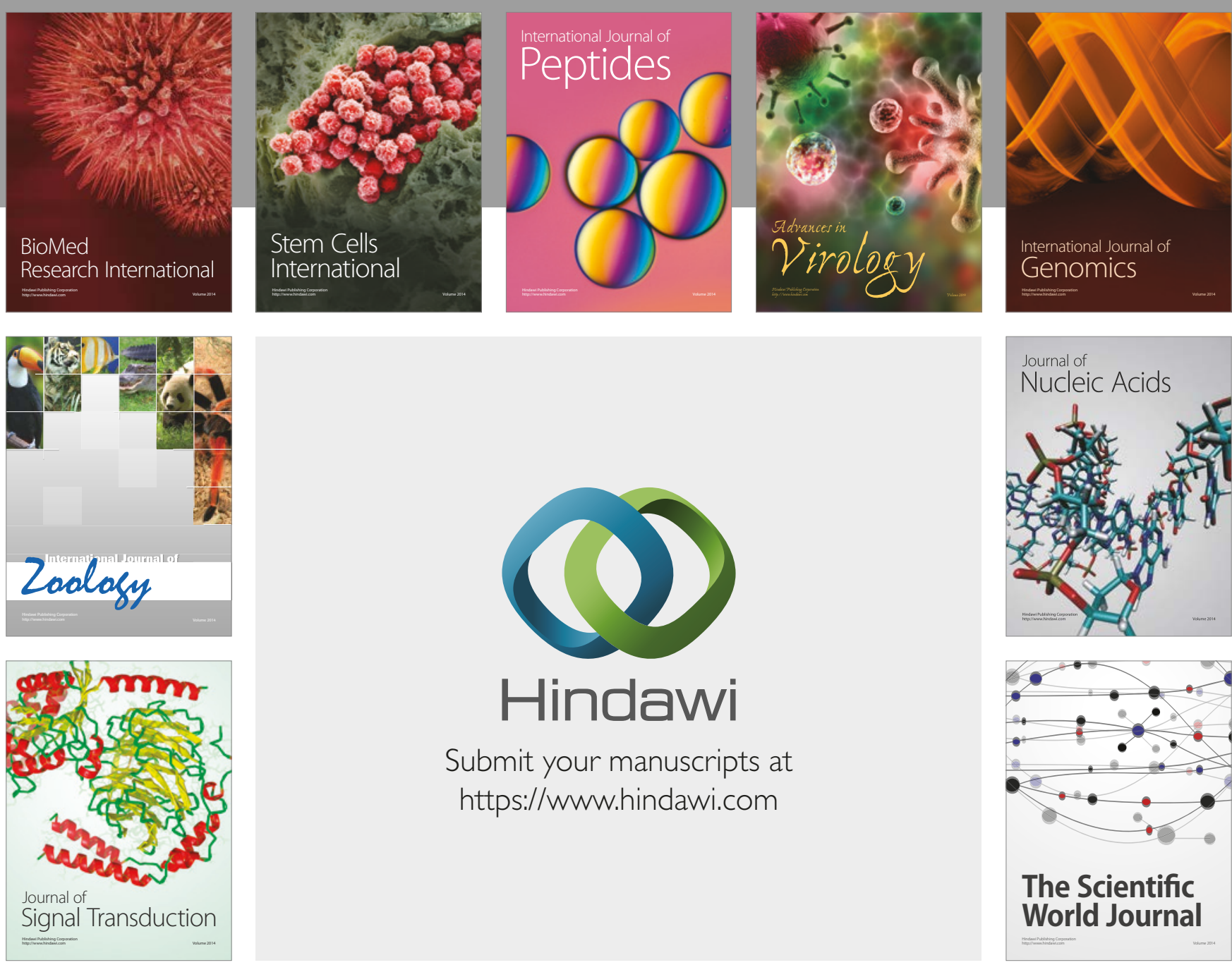

Submit your manuscripts at

https://www.hindawi.com
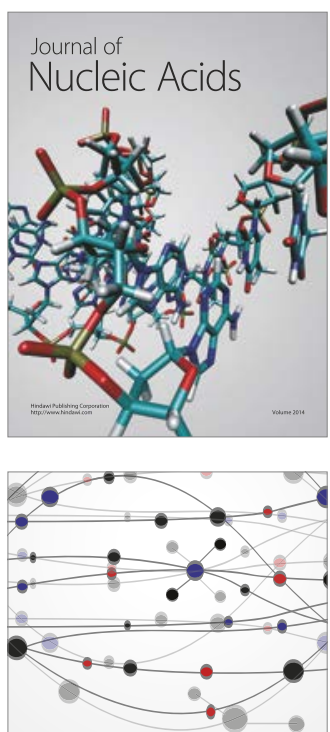

The Scientific World Journal

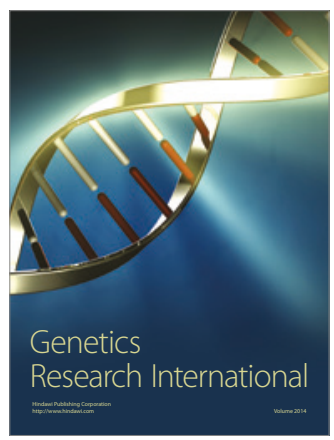

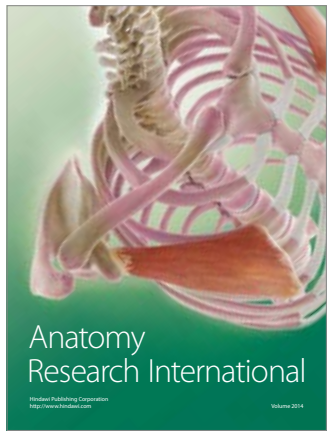

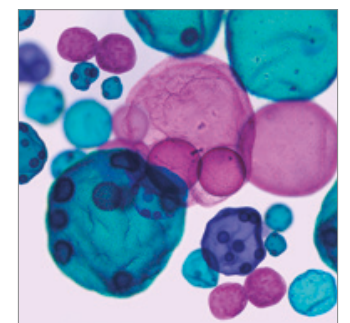

International Journal of Microbiology
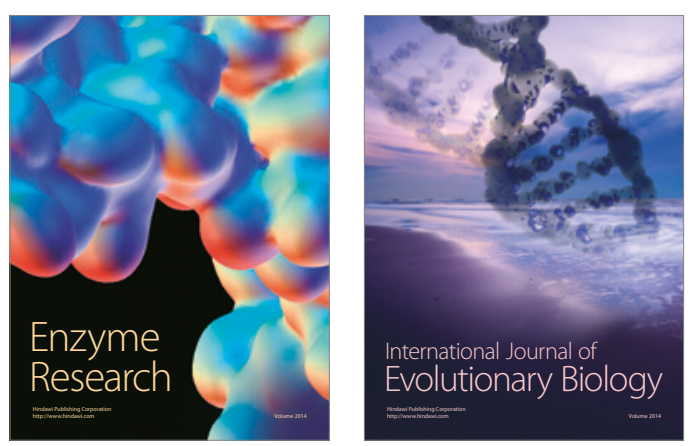
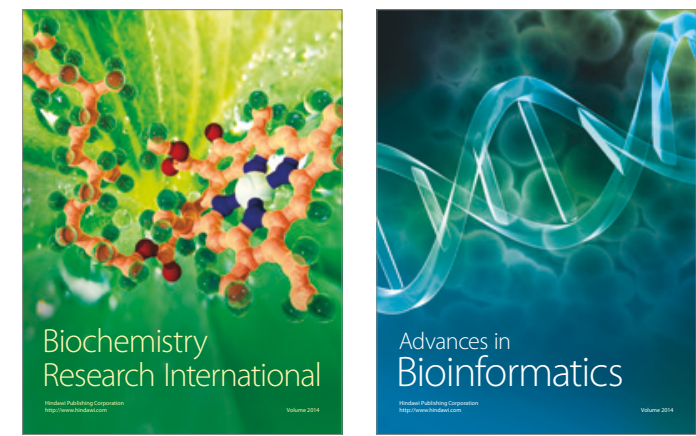

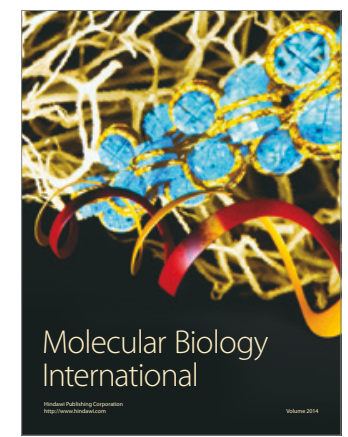

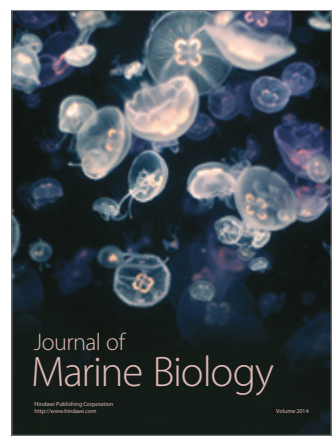

